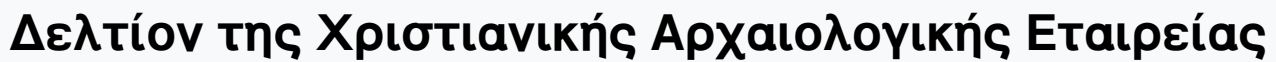

Tóp. 6 (1972)

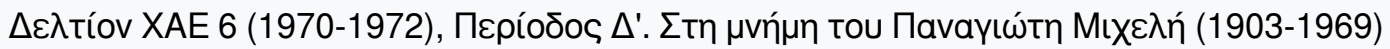

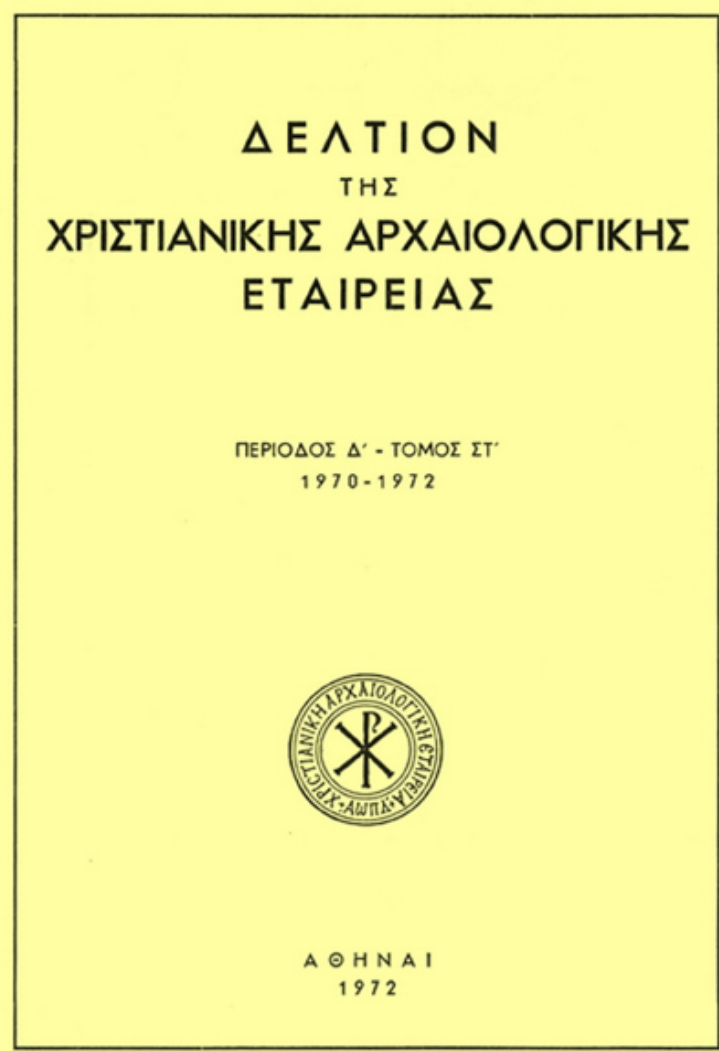

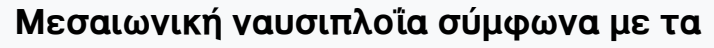

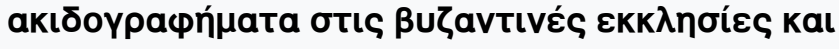

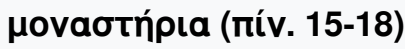

Otto F. A MEINARDUS

doi: $10.12681 /$ dchae.807

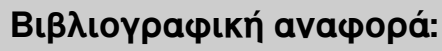

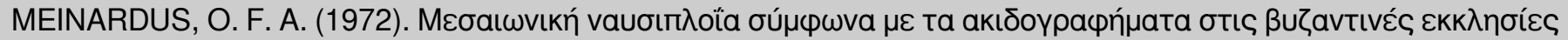

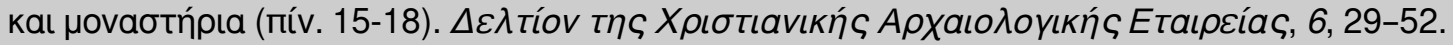

https://doi.org/10.12681/dchae.807 


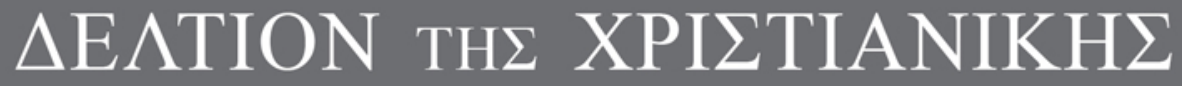 APXAIO $\Lambda$ OГIKH $\Sigma$ ETAIPEIA $\Sigma$}

Mediaeval Navigation according to Akidographemata in Byzantine Churches and Monasteries ( $\pi i v .15-18)$

Otto MEINARDUS

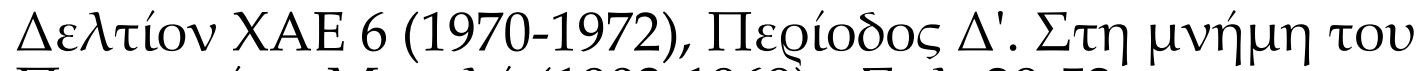

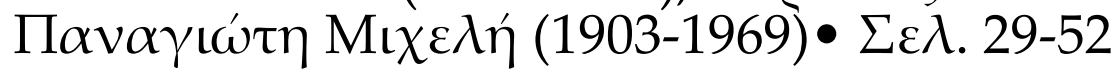

A@HNA 1972 


\section{MEDIAEVAL NAVIGATION ACCORDING TO AKIDOGRAPHEMATA IN BYZANTINE CHURCHES AND MONASTERIES}

(PL. 17 - 20)

The purpose of this study is to record the evidence of certain major types of mediaeval Mediterranean and Black Sea ships according to some selected akidographemata scratched by sailors in the walls of Byzantine churches and monasteries. Whereas this paper cannot claim to be all inclusive, we hope, nevertheless, to have collected sufficient material to justify an interim report on the subject. To the student of mediaeval Mediterranean and Black Sea maritime studies these akidographemata should be of significant assistance to his understanding of mediaeval navigation, in so far as they confirm but also clarify our knowledge of these vessels. Since these akidographemata are the scratchings of members of the respective crews, we should expect an emphasis on those parts of the ships with which the sailors were most intimately involved, i.e. the sails, the oars and the rudder. In fact, an analytical study of these akidographemata confirms this observation.

The great diversity of types of vessels represented in these scratchings is clearly noticeable. At the same time, however, it must be well understood that it is not always easy to determine the particular classification of a vessel on the basis of a single akidographema. As to-day, the peculiarities of the ships were largely determined by the requirements of the particular type of navigation, and we must distinguish between Mediterranean and Black Sea ships. Mediterranean ships in the Middle Ages were divided into two basic groups : the long ships, which were equipped with oars and were both low and narrow, and the round ships, which were dependent entirely on sails and were high and wide. From the XIIIth to the XVIth century, the galleys, were the dominant Mediterranean merchant - and war - ships. Normally, they had but one deck, a fighting platform in the bow, a larger and higher aftercastle, and between the oarsmen a gangway down the centre. The oarsmen were ranged on level benches on each side of the central gangway. These benches or thwarts were slanted obliquely towards the poop so that their inboard ends were further aft than their outboard ends. This slanting of the benches made it possible to have all these oars parallel without interfering with one another. Three rudders were normally carried by a galley, two designed to be projected 
from the sides of the stern when the ship was turned, and one built to fit the curved stern. These were controlled by a helmsman known to the Byzantines as the barkalas. The rudders were so effective that they excited the admiration of Joinville, who speaks about the ease with which the great XIIIth century Mediterranean ships turned to port and starboard as simply as a horse is turned with a rein. ${ }^{1}$ Related to the galley was the dromon, the selander, the griparion and the paraskalmion, the latter two being middle-sized caiques which were also very common in the Trebizond fleet. During the first few decades of the XVIth century the great galleys practically disappeared. Large crews made them expensive and the round ships were steadily improved. Moreover, as gunfire became a more important factor, the exposed state of the oarsmen's deck of the low galley placed the long ship under an increasing disadvantage, especially in combat with round ships. The round ships also replaced the galleys as merchant ships. The most important round ship in the Mediterranean was undoubtedly the carrack with its prominent main mast, which was larger than any other and carried a large square sail. The small mast in the forecastle was square-rigged; the one or two masts on the stern carried a lateen sail. These small lateen sails aft were especially helpful in enabling the ship to beat windward. Above the crow's nest on the mainmast there was added a small square sail. The carrack eventually led towards the full-rigged ship of many topsails and many masts. Smaller round ships were the cogs, the galeoni and the caravels. ${ }^{2}$

The larger ships which were introduced into the Black Sea by the Genoese were known as katerga and ranged from 400 to 600 tons burthen. Those which were equipped with oars were called tarida. Other ships which sailed the Black Sea were the barka, balka or barkopoula. The barka and karabia, though they varied in size, could be easily identified by their single masts, high poops and the fact that they had no oars. The smaller Black Sea ships of which there are numerous akidographemata scratched in the in - and outside walls of the churches of Trebizond were the griparia,

1. E. H. By r n e, Genoese Shipping in the Twelfth and Thirteenth Centuries, Cambridge Mass. 1930, p. 7.

2. L. B r é hier, La Marine de Byzance, Byzantion XIX, 1949, p. 12. He n ry and Renée Kahane, and Andreas Tietze, The Lingua Franca in the Levant, Urbana, U. of Illinois Press 1958. B jö rn Landström, The Ship. An Illustrated History, New York 1961. Fre de ri c C. L a n e, Venetian Ships and Shipbuilders of the Renaissance, Baltimore 1934. Fre deric C. L a n e, Venetian merchant galleys, Speculum XXXVIII, 1963, pp. 179-203. J. S c o t t a S, Les Messageries maritimes de Venise, Paris 1929. A le the a W i e 1, The Navy of Venice, London 1910. 
the paraskalmia and the xylaria. They were small single-masted transport ships. ${ }^{3}$

The purpose of these akidographemata should be seen in the religious sphere. I propose that they are to be regarded as votive offerings of sailors prior to or after long and perilous voyages. ${ }^{4}$ The widespread practice of scratching akidographemata in the walls of the churches and monasteries seems to support the assumption that they were expressions of devotion of gratitude for blessings or of supplications for divine protection. Instead of scratching their coats-of-arms, their names or their initials in the walls, these men identified themselves so intensely with their respective ships that they projected their vessels as votive offerings.

Whereas it is impossible to determine the exact extent of the custom of scratching ships in the walls of churches and monasteries, I have found evidence of this practice as far east as in the Armenian Orthodox Monastery of St. Thaddaeus in Azerbaidjan and throughout the Pontus region, as far west as Ohrid in southern Yugoslavia, and as far south as Mistra on the Peloponnesos as well as in many of the Greek Islands and Cyprus. Normally one would expect these akidographemata in the churches and monasteries which are situated near the coastline or in or near a port. However, it is noteworthy that many of these scratchings are found in churches and monasteries far removed from the shores, as it will be seen from the sites mentioned in this study. This means that either individual sailors, or more probably whole crews, attended certain panegyri in order to receive blessings of protection for their maritime undertakings.

Yet, it still remains to be investigated why the sailors selected only certain churches and monasteries to scratch their akidographemata in the walls. On the first sight one would expect that churches and monasteries dedicated to St. Nicholas, the patron of sailors, would be sought after by sailors, and in some instances this is also the case, as e.g. in the Church of St. Nicholas of Mavrika in Paleochora, Aegina. In Salonica, however, the church having the largest number of akidographemata is the XIIIth century Church of the Prophet Elias in the Upper City. The particular dedication of the church,

3. A $\mathrm{nth}$ on y B r yer, Shipping in the Empire of Trebizond, The Mariner's Mirror, LII, 1, 1966, pp. 3-12.

4. These votive offerings should be compared to the numerous golden and silver models of ships in such places as the Church of the Evangelistria, Tinos. Here also is the famous votive model of the ship with the swordfish that saved the ship from being wrecked. In the Church of Nea Mone in Chios there is a sponge which sailors offered in gratitude, for that particular sponge prevented their ship from being wrecked. 
therefore, does not necessarily determine its attraction to and by the sailors. Moreover, there is no reason to assume that all of these akidographemata were the pious expressions of Greek sailors. For that matter, it is quite likely and even probable that some of these scratchings represent the ships of Venetian and Genoese sailors.

The following chapter lists some of the churches and monasteries in which we have discovered some akidographemata. Unfortunately, many mediaeval churches and monasteries which undoubtedly were ((adorned) with those scratchings are either totally destroyed, or they have been rebuilt in such manner that the mediaeval graffiti and akidographemata were obliterated in the process of reconstruction. This, for example, has been the case in the famous former Church of St. Saviour in Chora (Kahriye Camii) in Istanbul. We shall list the churches and monasteries in the following order: The Pontus region, Azerbaidjan, Western Anatolia, Istanbul, Yugoslavia, Northern Greece, Attica, the Peloponnesos, the Greek Islands and Cyprus.

CHURCHES AND MONASTERIES WITH MEDIAEVAL AKIDOGRAPHEMATA OF SHIPS

David Winfield asserts that there are about one hundred scratchings of ships in the walls of the Church of Hagia Sophia in Trebizond, principally in the narthex and on the outside walls of the apses. ${ }^{5}$ True, the outside walls of the three apses are adorned with numerous very instructive akidographemata and I have counted eight ships on the outside wall of the southern apse, thirtythree ships on the outside wall of the central apse, and fifteen ships on the outside wall of the northern apse of the Church of Hagia Sophia. Among these akidographemata there are the two Genoese one-masted barkae with their very high poop (Pl. $17 \mathrm{a}-\mathrm{b}$ ). In the case of the ship (Pl. 17a) the Genoese origin can be clearly seen on account of the Cross of St. George, the symbol of Genoa, at the poop. In this context we must remember that the Church of Hagia Sophia is situated only two miles west of the port of Daphnous where the Genoese had their own Latin chapel. ${ }^{6}$ The most noteworthy akidographemata, however, are those which are scratched in the outer wall of the southern part of the narthex. There is the scratching of a small round ship, a barka or karabia with two masts and a very high poop (P1. 18a) and that of a galley equipped with a ram and two heavy lateral rudders

5. David Talbot Rice, The Church of Haghia Sophia at Trebizond, Edinburgh University Press, 1968. D a v i d W in f i e l d, Ayasofya Trabzon, Turk Arkeoloji Dergisi XI, 1961, p. 39. A. B r y e r, op. cit., p. 5.

6. To this day the Latins maintain a Church of Santa Maria in Trebizond. Cf. A. B r y e r, Trebizond and Rome, Archeion Pontou, XXVI, 1964, pp. 298 f. 
(timones) (Pl. 18b). Drawings of eight akidographemata in Hagia Sophia were published by David Talbot Rice, ${ }^{\top}$ while Anthony Bryer published nine drawings ${ }^{8}$ some of which are the work of Mrs. June Winfield. ${ }^{9}$

Other interesting scratchings of small Black Sea coastal vessels can be found on the outside wall of the northern apse of the former Church of St. Eugenios (Yeni Cuma Camii) in Trebizond, and four akidographemata can still be identified on the outside wall of the southern apse of the former Church of the Panagia Chrysokephalos (Ortahisar or better known as the Fatih Camii) in Trebizond. The walls of the sadly damaged former Church of the Panagia Theoskepastos on the slope of Boz Tepe in Trebizond must have been used by many sailors for their scratchings of pictures of ships. Because of the severe damage I could identify only two akidographemata. From the above mentioned examples it is quite evident that at least in the Pontus region the sailors preferred to scratch their akidographemata and their graffiti in the outer walls of the apses. The same practice I noticed in the abandoned Byzantine Monastery of the Panagia Soumela near Maçka in the Pontic Alps, ${ }^{10}$ where among the numerous Greek, Armenian, Arabic and Turkish graffiti there are at least four distinctive akidographemata of ships on the outside wall of the apse of the principal church. The scratching of the caravel (P1. 18c) is found on the north wall of the Church of the Holy Virgin in the Monastery of the Panagia Soumela near Maçka.

As one travels further east towards Azerbaidjan one becomes aware of the full geographical extent of this pious practice. On the south and north walls of the choir of the principal church in the Armenian Orthodox Monastery of St. Thaddaeus near Shahabad, Makoo, in north-western Iran, there are five very simple akidographemata of small coastal vessels, which could have been used on Lake Urmia (P1. 18d). Although I have not noticed any akidographemata of ships in mosques, it is worth recording that I saw an akidographema of an anchor scratched in the wall of the Great Mosque of Malikaz-Zahir in the Citadel of Aleppo in Northern Syria. According to W. Wulzinger, akidographemata of ships were also found scratched in the walls of a bath near the Delphinion at Miletus in Western Turkey. ${ }^{11}$

7. D. T. R i ce, op. cit., pp. 249-251.

8. A. B r y e r, Shipping in the Empire of Trebizond, The Mariner's Mirror, LII, 1, 1966, pp. 6, 9, 10.

9. D. W in f i e ld, loc. cit.

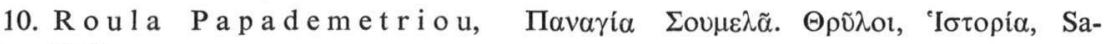
lonica 1968.

11. W. Wulzigner, P. Wittek, E. Sarre, Das Islamische Milet, Berlin 1935, p. 53. 
Whereas once upon a time the walls of many of the mediaeval churches and monasteries in Istanbul were used for pious scratchings, we must report that the evidence of these akidographemata has disappeared, largely due to the destruction or the conversion of these churches into mosques. On the north-eastern column in the southern gallery of the former Church of Hagia Sophia in Istanbul I found an unusually large akidographema of an onemasted galley.

Akidographemata of ships similar in their appearance to those used in the Pontus region are also found on the walls of the upper narthex of the Church of Hagia Sophia at Ohrid in southern Yugoslavia. ${ }^{2}$

In northern Greece, there are very many churches and monasteries which were visited by sailors who left their scratchings of ships on the walls of the respective sanctuaries. In this context it is impossible to mention all the churches with akidographemata of ships, and we have limited ourselves in our listing to those churches with the most significant akidographemata. On the northern outside wall of the Monastery of Vlatadon of the Upper City of Salonica there is an interesting akidographema of a three-masted galleon (Fig. I, 27). ${ }^{13}$ Other churches with scratchings of ships in the Upper City of Salonica include the Church of St. Catherine, where a small sailing vessel is found on the wall of the narthex. The Church of the Prophet Elias, on the other hand, must have served as a special pilgrimage shrine for sailors if one judges by the large number of akidographemata of ships on the southern and western walls as well as on the outside wall of the narthex. The ships, which are portrayed in fig. I, 25 and 26 are found on the east wall of the southern nave in the Church of the Holy Apostles in Salonica. ${ }^{14}$ The akidographema on the north wall of the narthex of the church in the Monastery of Olympiotissa at Elasson represents a galley or a dromon (fig. I, 28). ${ }^{15}$

There is no question that the walls of many of the mediaeval churches in Verriawere covered with numerous scratchings. I noticed a badly damaged akidographema of a ship, the type of which could not be identified, on the north wall of the Church of St. Andreas in Verria. A large number of ships of the most varied types is scratched in the walls of at least six churches in Kastoria,

12. P. Milk ović-Pe pek, Meterijali za makedonskata srednovekovna umetnost. Freskite vo svetilisteto na cravata sv. Sofija vo Ohrid, Zbornik na Arheoloskiot muzejSkopje, I, Skopie, 1956, pp. 37-67.

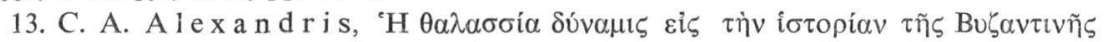

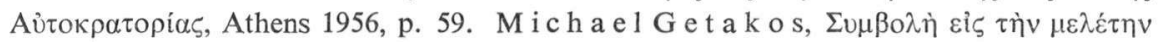

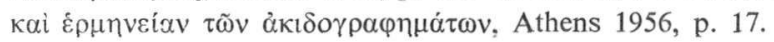

14. M. G e t a k o s, loc. cit.

15. C. A. Alexandris, loc. cit. M. G e t a k o s, loc. cit. 
namely, the Church of the Unmercenary Saints, the Church of the Panagia Mavriotissa, the Church of St. Athanasios of Mouzake, the Church of St. Alypios of Papastamitou, the Church of St. John the Theologian Mavriotissa and the Church of the Panagia of Archontos Apostolake. ${ }^{16}$

In the Church of St. Luke of Stiris (Hosios Lukas) near Delphi I have copied altogether seventeen scratchings of various types of Mediterranean
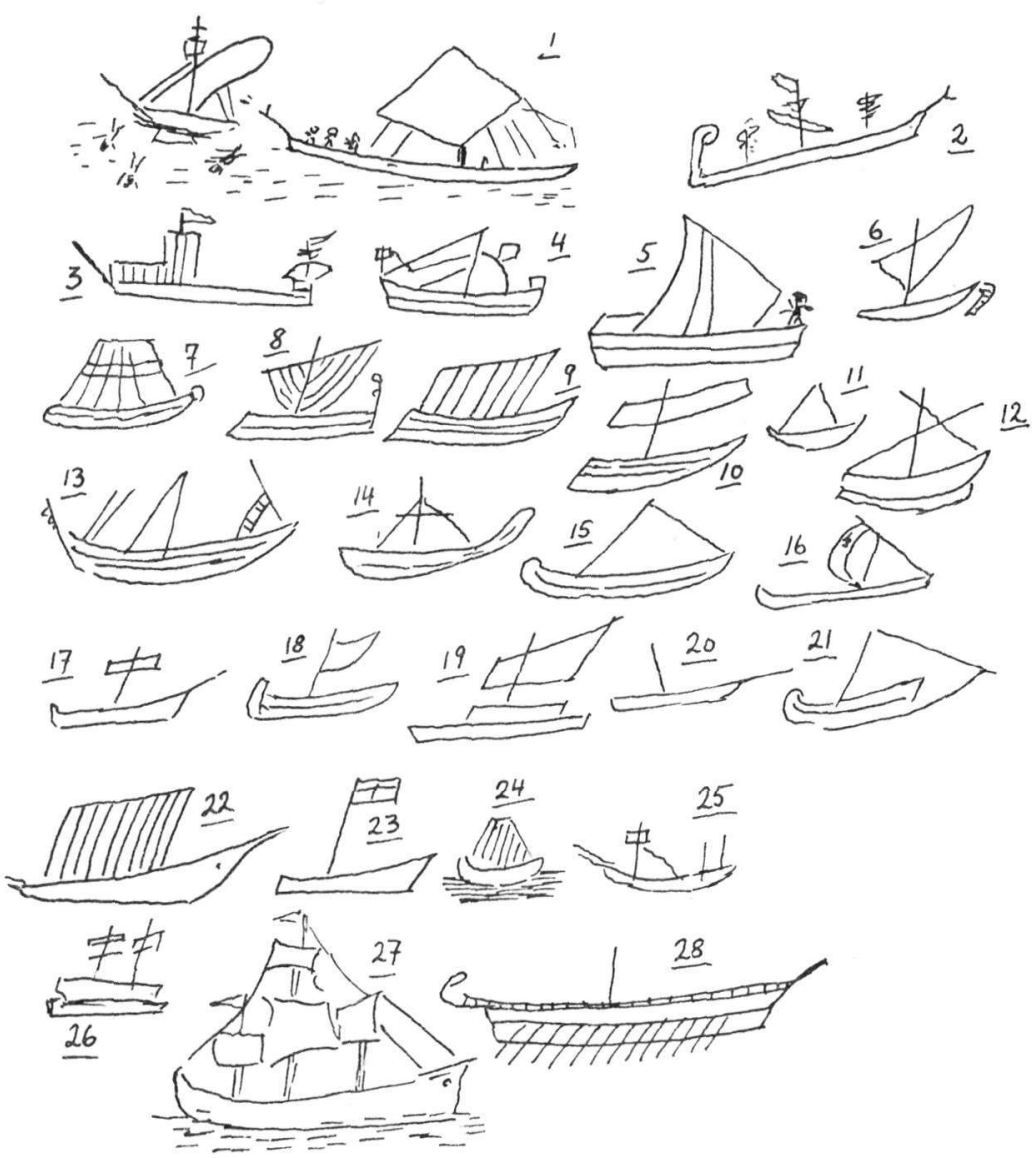

Fig. I.

ships, twelve of which are found on the north, east. south and west walls of the southern gallery of the principal church, while five akidographemata are scratched in the east and west walls of the southern narthex of the subterranean

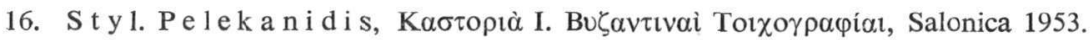
Cf. the following plates, $13 \mathrm{~B}, 84,85,145 \mathrm{~A}, 145 \mathrm{~B}, 152 \mathrm{~A}, 154 \mathrm{~B}, 178,208 \mathrm{~A}, 213 \mathrm{~A}, 242 \mathrm{~B}$. 
Church of St. Barbara. The akidographemata on the walls of the gallery represent four different types of ships, namely the carrack (P1. 19a-b), the cog, the caravel (Pl. 20a) and the galley (P1. 20b), while the ships on the walls of the Church of St. Barbara belong to three different categories, the galleon, the dromon and the selander. ${ }^{17}$

A rather interesting akidographema of a galleon or a caravel is found in the church of the Monastery of the Blessed Meletios between Eleusis and Megara, Attica. ${ }^{18}$ Only a few miles west of this monastery there is the Church of Christ the Saviour in Megara, on the west wall of which there is a scratching of a caravel showing also a sailor aboard (fig. I, 5). ${ }^{19}$ In the famous monastery church of Daphne one can discover three severely damaged akidographemata of ships scratched in the painting of St. Cosmas.

In the Church of the Panagia in Galatsi in Athens there is a rather unusual akidographema portraying a sea-battle. A dromon had rammed a vessel of which only the sinking stern in visible. ${ }^{20}$ A small caravel is scratched in the south wall of the Church of St. John at Acharnes, a suburb of Athens. ${ }^{21}$ In his study on the Omorphe (the beautiful) Church in Athens Prof. Orlandos has published two akidographemata of ships representing one galley and one dromon. ${ }^{22}$ One of the most significant collections of akidographemata is found on the walls and on the columns of the Hephaistion on the Kolonos Agoraios dominating the Agora of Athens. ${ }^{23}$ It is very likely that at the time of the visits of the sailors, who scratched their ships in the walls and columns, this site was still used as the Church of St. George.

In the course of the excavations of Corinth, Theodore L. Shear discovered on the walls of a Byzantine cistern three ships crudely scratched in outline in the stucco with which the walls are faced. Here, the vessel on the south

17. Whereas some of the akidographemata in the Church of St. Barbara were published by C.A. A lexandris, op. cit., p. 73, fig. 2, those scratched in the walls of the gallery of the main church have not been previously published. R. W. Schultz and S. M. Barnsley, The Monastery of St. Luke of Stiris, in Phocis, and the Dependent Monastery of St. Nicholas in the Fields, near Scripou in Beotia, London 1901. C. D i e h l, L' église et les mosaïques du couvent de Saint-Luc en Phocide, Paris 1889.

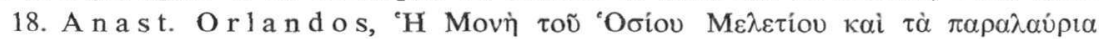

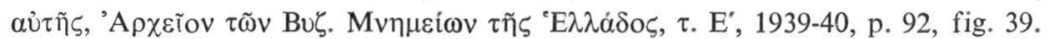

19. C. A. A l ex a n d ris, op. cit., p. 59. M. G e t a k o s, loc. cit.

20. C. A. A 1 ex a n $\mathrm{d}$ is, loc. cit.

21. C. A. A l ex a n d r is, loc. cit.

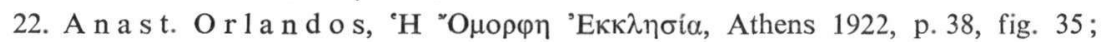
p. 40 , fig. 39 .

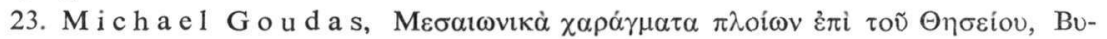

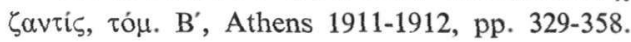


side is the most elaborately drawn with its masts, spread sails and banks of oars. $^{24}$ The akidographemata (fig. I, 22-24) on the north wall of the Church of the Koimisis of the Holy Virgin in Ligourion, Nauplion, represent three different types of vessels, which, however, cannot be identified as to their particular type..$^{2 t}$ It is understandable that sailors would repair to the Byzantine city of Mistra, and the vessels which are scratched in the walls of the buildings of Mistra are largely galleys. ${ }^{26}$

To the student of mediaeval graffiti and akidographemata the island of Aegina offers almost unlimited opportunities. In the Church of St. Nicholas of Mavrika in Paleochora I have copied thirteen ships. In the Church of St. George in Paleochora we find in addition to several akidographemata of ships (fig. I, 2-4) also a sea-battle between a dromon using the Greek-fire and a galley. The galley seems to be sinking since the sailors are seen jumping into the water (fig. I, 1). ${ }^{27}$ Three small ships are scratched in the north wall of the Church of the Holy Cross in Paleochora (fig. I, 19-21), ${ }^{8}$ while some nine akidographemata of sailing vessels are found on the north wall of the Church of the Prophet Elias in Aegina (fig. I, 6-14)..9 As in the case of the churches in the Pontus region, so we find also in Aegina that sailors scratched their ships in the outside walls of the churches. A good illustration of this practice in Aegina are the akidographemata of four small coastal vessels on the northern outside wall of the Omorphe Church in Aegina (fig. I, $15-18) .^{30}$

On the island of Paros I saw four drawings of galleys on the two northern marble columns of the baptistery of the Church of Panagia Hecatonpyliani. Also on the island of Patmos I noticed damaged akidographemata of several one-masted coastal vessels on the south and west walls of the Church of St. Basil in Chora. Several ships are also scratched in the walls of the Encleistra (St. Neophytos) at Paphos in Cyprus. ${ }^{31}$

As stated above, this listing of churches and monasteries should not be considered in any way complete. We must assume that the mediaeval sailors

24. Theodore Leslie Shear, Excavations and Tombs of Corinth, American Journal of Archaeology XXXIII, 1929, p. 525.

25. M. Getak o s, loc. cit.

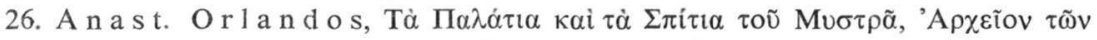

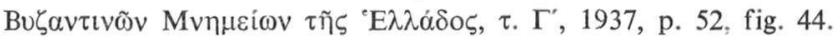

27. M. G e t a k o s, loc. cit.

28. Ibid.

29. Ibid.

30. Ibid.

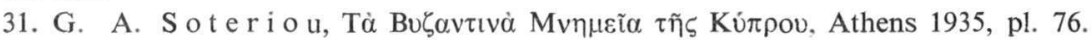


were quite accustomed to leave their graffiti or akidographemata wherever they went to worship.

TYPES OF SHIPS USED IN THE MEDITERRANEAN ACCORDING TO MEDIAEVAL AKIDOGRAPHEMATA

In the introductory remarks we have referred to two basic kinds of ships which sailed the Mediterranean Sea from the XIIth to the XVIth century, namely the long and the round ships. For this study we have selected a representative group of forty akidographemata of the principal types of ships. ${ }^{32}$ In addition to the ten beautiful and elaborate akidographemata scratched in the walls and the columns of the Hephaistion in Athens, we shall include eleven akidographemata from the Monastery of St. Luke of Stiris near Delphi, nine akidographemata from the Church of St. Nicholas of Mavrika at Paleochora on the Island of Aegina, four akidographemata from the Church of the Prophet Elias in Salonica, and one akidographema each from the following churches : The Church of St. Meletios in Attika, the Church of St. Athanassios of Mouzake in Kastoria, the Omorphe Church in Athens, the former Church of Hagia Sophia in Trebizond, the former Church of Hagia Sophia in Istanbul, and the Church of St. Thaddaeus in Azerbaidjan.

Having divided the mediaeval ships into two basic kinds, the long and the round ships, we have arranged the following material so as to differentiate altogether between seven types of ships, four types of long ships, one (hybrid) type, and two types of round ships. In the following pages we shall discuss the important characteristics of the small galley, the two masted galley, the larger galley, the dromon, the galleon, the caravel and the carrack.

\section{The Galley.}

We shall commence with the various types of long ships, i.e. the galley, the dromon and the selander. Among the galleys we must distinguish between the one-masted galley, the two-masted galley and the large galleys. We have selected eleven akidographemata representing the different types of the one-masted galley. These relatively small ships were coastal traders and in many ways they were similar to the gripo or the griparion, which Dawkins translates with the word ((caique)). ${ }^{33}$ It is not surprising that by far the majority

32. For an analytical description of the various types of Black Sea ships, cf. A. B rye r, Shipping in the Empire of Trebizond, The Mariner's Mirror, LII, 1, 1966, pp. 3-12.

33. E. R. M. D aw ki in s, Leontios Machairas Recital concerning the Sweet Land of Cyprus entitled 'Chronicle', vol. II, Oxford 1932, p. 133. 
of the akidographemata, especially in the churches and monasteries of the Greek Islands, represent these small galleys. Noticeable in almost all of these scratchings are the oars, the rudder, and midships the long bridge
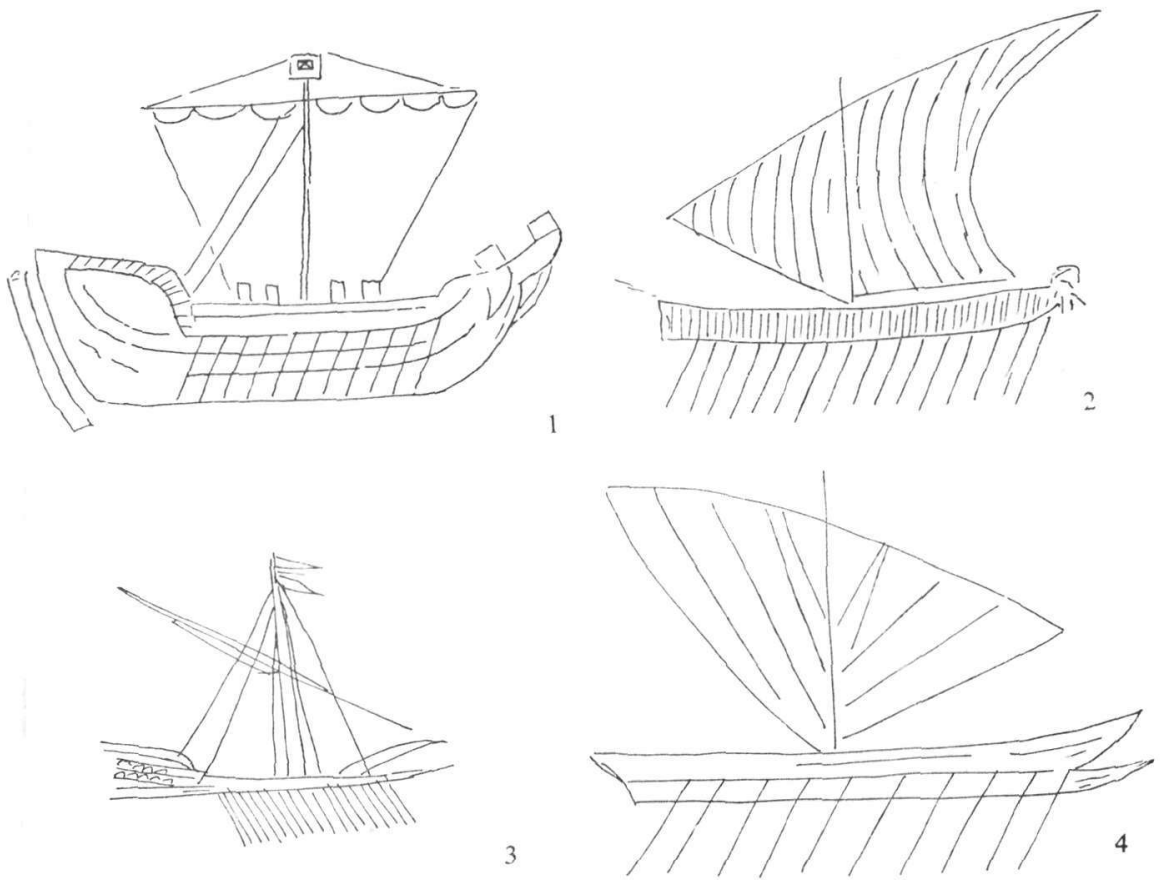

Fig. II.

between the oarsmen, known as the corsia. The majority of these galleys were probably merchantmen and biremes with two men occupying one bench on either side.

Fig. II,1. Location: The former Church of Hagia Sophia, Istanbul, north-eastern column of the southern gallery. This ship, which appears rather bulky, is a larger one-masted galley. Very clearly marked is the rudder.

Fig. II, 2. Location: The Church of St. Nicholas of Mavrika, Aegina, south wall. This ship represents a small coastal vessel, used for the interisland traffic probably in the Saronic Gulf.

Fig. II, 3. Location: Hephaistion, sixth column from the east, northern row of columns. This vessel may be a galley or a dromon. The oars project through round oar-ports in the planking. The yard of the lateen is very long, though there were ships of this type with a yard even longer than the length of the 
ship. In the stern we notice the poop, which is known as the "ebed of the kentarchos" 3 , the cabin of the captain. ${ }^{34}$

Fig. II, 4. Location : The Church of St. Nicholas of Mavrika, Aegina,
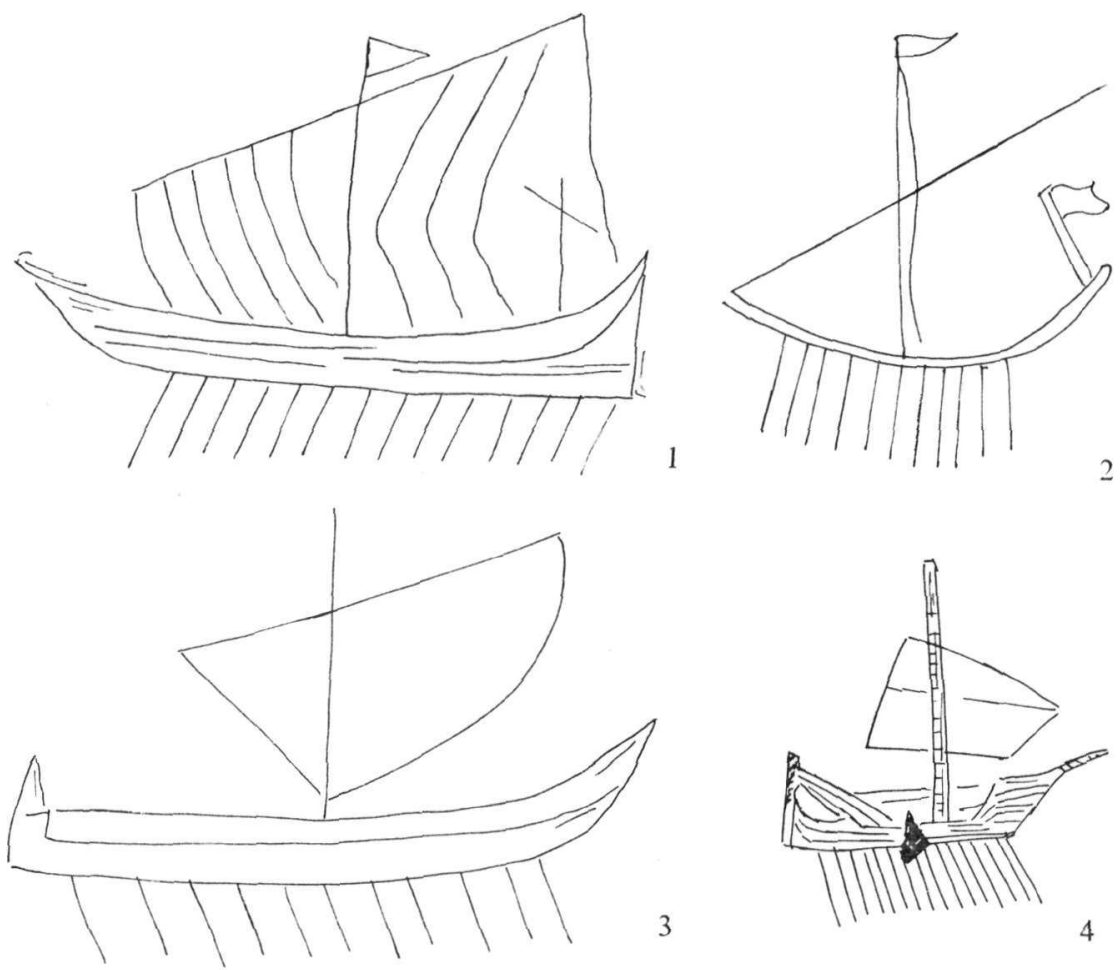

Fig. III.

south wall. This one-masted galleys is a small war-ship, since it is equipped with a ram above the water-line.

Fig. III, 1. Location: The Church of St. Nicholas of Mavrika, Aegina, south wall. A one-masted galley, which was used as a coastal vessel.

Fig. III, 2. Location: Hephaistion, central column, western row of columns. This kind of rough and almost careless scratching was very popular. We have included this particular galley to demostrate this type of akidographema which is found in many churches and monasteries. Again we notice the long yard and the emphasis on the flags on top of the mast and stern. ${ }^{35}$

34. M. G o u d a s, op. cit., No. 10.

35. M. G oud a s, op. cit., No. 12 . 
Fig. III, 3. Location: The Church of St. Nicholas of Mavrika, Aegina, south wall. This one-masted galley is very similar to figs. II, 2; II, 4; III, 1.

Fig. III, 4. Location : The Church of St. Luke of Stiris, gallery, west wall.
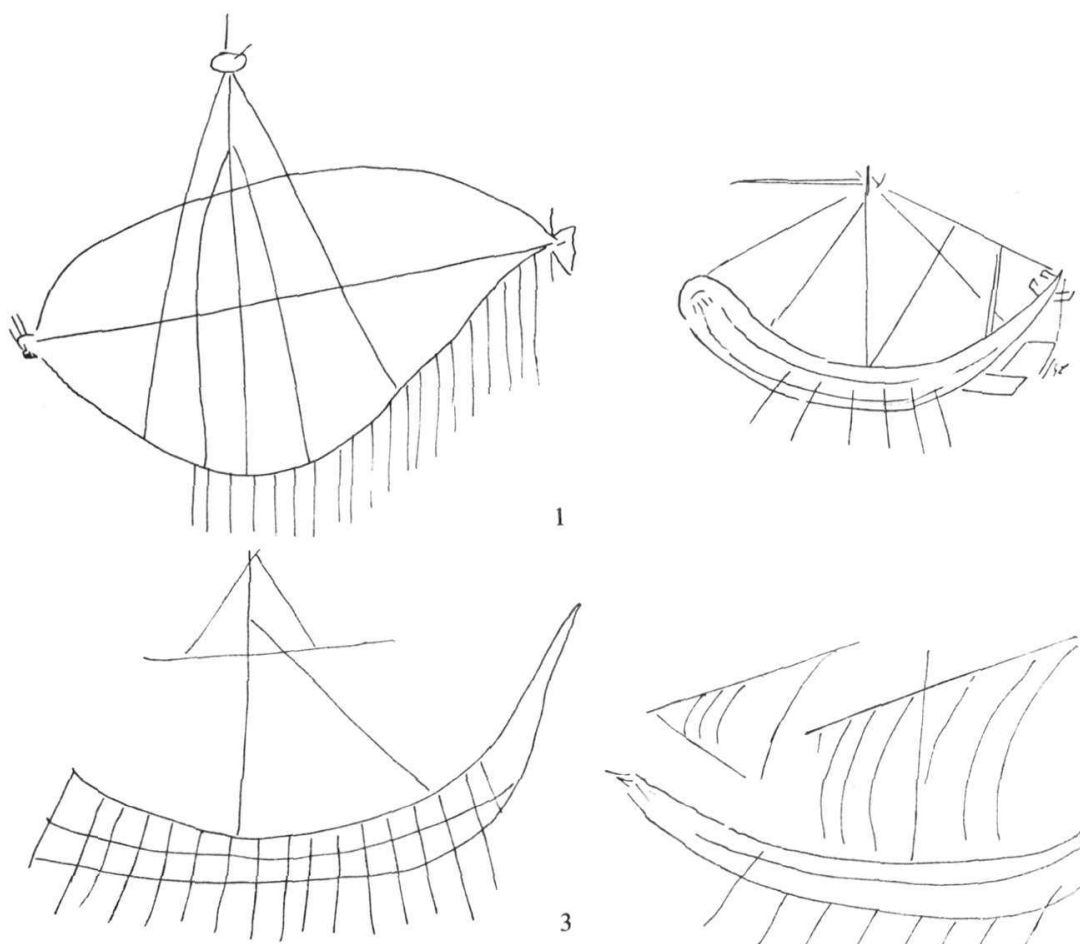

Fig. IV.

This one-masted galley was probably a bireme. The two horizontal lines may indicate the bridge between the oarsmen. Noticeable are the sturdy planks, which gave much strength to the vessel fore and aft. The rudder can be clearly identified.

Fig. IV, 1. Location: The Church of St. Luke of Stiris, gallery, north wall. This akidographema shows a one-masted galley similar to those which we have presented above. A bird's eye view seems to be attempted, though the oars on starboard are missing. A bowsprit as well as a stern-rudder are indicated. The centre line may be intended to signify the corsia.

Fig. IV, 2. Location: The Church of St. Luke of Stiris, gallery, east wall. This merchantman has certain similarities to a gripo. Very pronounced is the rudder, probably indicating a double rudder and an anchor. Also notice 
the tackles for tightening the shrouds. Similar vessels are scratched on the outside walls of the apses of the above mentioned former churches in Trebizond, Pontus.

Fig. IV, 3. Location: The Church of St. Nicholas of Mavrika, Aegina, south wall. A typical coastal vessel similar to fig. III, 3.

II. The Two-masted Galley.

The two-masted galleys were somewhat larger than the above mentioned vessels. They had a high orlum or poop. The smaller foremast was referred
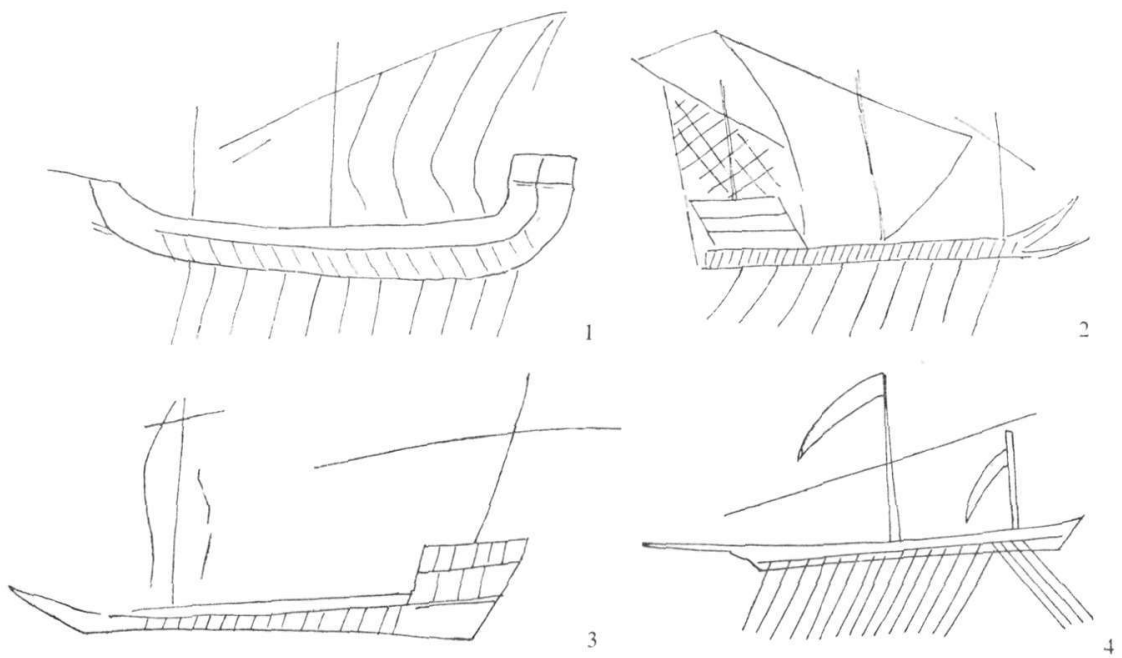

Fig. V.

to as the arbor de prova or just de proda, while the larger mainmast was known as the arbor de medio.

Fig. IV, 4. Location: The Church of St. Nicholas of Mavrika, Aegina, south wall. Note the structure of the stern, the stern-post being rounded off to enable the ship to be beached stern first.

III. The Larger Galley.

The larger galleys were used for long distance sailing. Usually they had several masts and as many lateen sails for use in light airs. They were biremes or triremes and very often the poop had several decks. In some ways they were similar to the dromon.

Fig. V, 1. Location : The Church of St. Nicholas of Mavrika, Aegina, 
south wall. The well developed stern places this two-masted galley among the larger galleys. The pronounced orlum and the proda are strikingly displayed.

Fig. V, 2. Location: The Church of St. Nicholas of Mavrika, Aegina, north wall. This large galley is a man-of-war as seen by the ram above the water-line, probably a Venetian or Genoese vessel.

Fig. V, 3. Location: The Church of St. Athanasios of Mouzake, Kastoria. This large galley is very similar to fig. V, 2 . The lines on the hull should be interpreted as representing the oars. ${ }^{36}$

\section{The Dromon.}

The dromon is a fast galley, which very often was used as a man-of-war. Typical is the length of the vessel and the single flat deck which was almost wholly occupied by the oarsmen.

Fig. V, 4. Location: The Church of St. Luke of Stiris, east wall of the narthex of the subterranean Church of St. Barbara. This dromon was either a bireme or a trireme with approximately twenty benches on either side. The oars projected through oar-ports in the planking. A remarkable detail is the unusually long ram, which lies well above the water-level. As in the case of the galleys we notice the long yard of the lateen sail. ${ }^{37}$

Fig. VI, 1. Location: Hephaistion, south wall of the temple. This akidographema is damaged by a bullet. This low and slender ship should be assigned to the group of the fast galleys, being either a dromon or a selander. ${ }^{38}$

Fig. VI, 2. Location: The Church of St. Nicholas of Mavrika, Aegina, south wall. This akidographema illustrates well that there were many vessels of this type which had a yard longer than the ship. The ram indicates that this dromon was a man-of-war.

Fig. VI, 3. Location: Omorphe Church, Athens. This is one of the relatively few akidographemata which portrays members of the crew, the sailor at the stern and another sailor at the anchor. ${ }^{39}$

Fig. VI, 4. Location: The Church of St. Luke of Stiris, east wall of the narthex of the subterranean Church of St. Barbara. Noticaeble is the castle at the stern. The oarsmen are indicated by small circles. The line in front of the castle indicates a side-rudder.

Fig. VII, 1. Location: The Church of St. Luke of Stiris, east wall of the

36. Styl. Pelekanidis, op. cit., pl. 154 B.

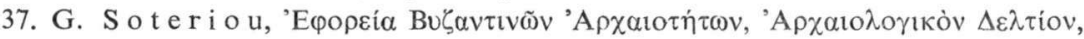
VI, $1920-21$, p. 186.

38. M. Goudas, op. cit., No. 21.

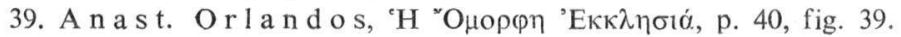


narthex of the subterranean Church of St. Barbara. This long ship, known as a selander, $\chi \varepsilon \lambda \alpha$ d $\delta \delta$ เov, belongs to the class of the "erunners". Like the dromon, the selander was either a bireme or a trireme. The selander used to carry as many as $\mathbf{1 2 0}$ men for the crew. Again we notice the unusually long yard, which has the same length as that of the ship. The ram of this man-of-war lies at the water-line. Often the selanders were equipped with the " Greek
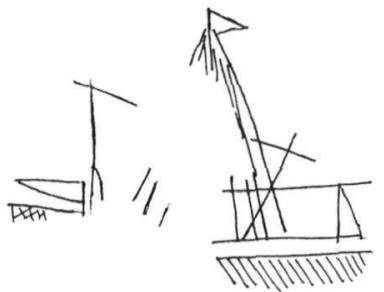

1

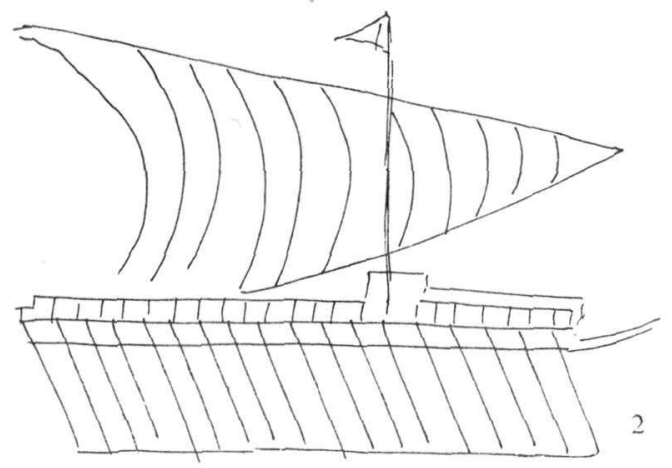

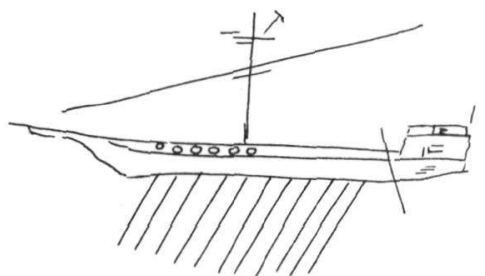

4

Fig. VI.

fire". The rudders seem to be so designed as to be projected from both sides of the stern. Whether the sail(?) on the stern indicates a bonaventura is very questionable. ${ }^{40}$

Fig. VII, 2. Location: Hephaistion, third column from the east, northern row of columns. This vessel is either a dromon or a selander. The members of the crew are clearly shown and the rudder is very prominent. ${ }^{41}$

\section{$V$. The Galleon.}

The galleon is a hybrid ship which was developed in the XVIth century.

40. C. A. A lexandris, op. cit., p. 72.

41. M. G o u d a s, op. cit. No. 2. 
Most of the galleons were war-ships. In many ways, they are similar to the large round ships, though slimmer and lower. Galleons of this type defy easy classification under the categories of round ship or long ship. The mainmast and the foremast have square sails, the small mizzen aft of the mainmast has a lateen sail to help steering.

Fig. VII, 3. Location: The Church of the Prophet Elias, Salonica, nar-
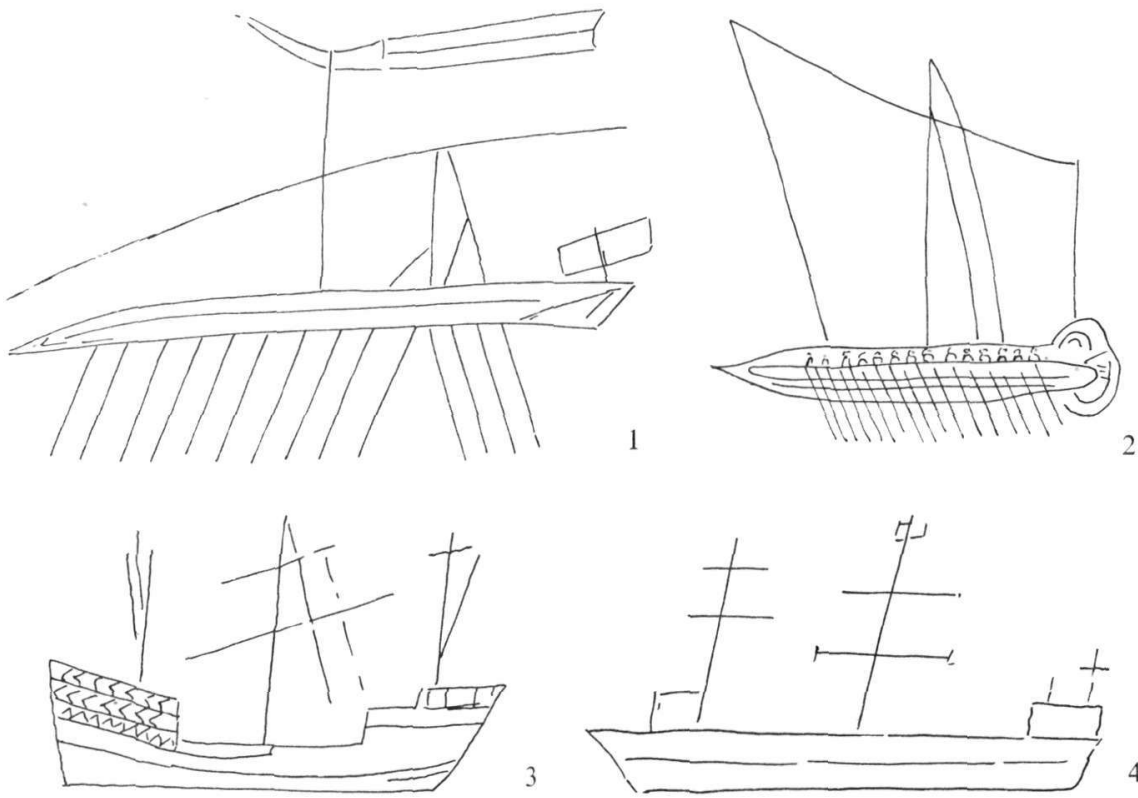

Fig. VII.

thex. This galleon served as a merchant-ship. The forecastle is within the bow, the high aftercastle has three decks. The mizzen is clearly indicated.

Fig. VII, 4. Location: The Church of St. Thaddaeus, Azerbaidjan, north wall of nave. This three-masted galleon is a merchant-ship. It is noteworthy that we should discover an akidographema of this type of vessel so far removed from the nearest Black Sea port.

Fig. VIII, 1. Location : The Church of St. Luke of Stiris, west wall of the narthex of the subterranean Church of St. Barbara. The forecastle of this three-masted galleon is within the bow and proceeds from the hull itself, almost as a sort of continuation of the deck and bulwarks. The powerful ram sits high above the water-level. The forecastle is constructed of two decks, so is 
the aftercastle. Above the ram there is a long bowsprit for the artemon or spritsail. On the foremast and mainmast there is a crow's nest which in both cases is surmounted by a small square topsail. The four rectangular openings on the main deck and the four rectangular openings on the quarter deck served as gunports for heavy artillery. Two guns project from the stern.
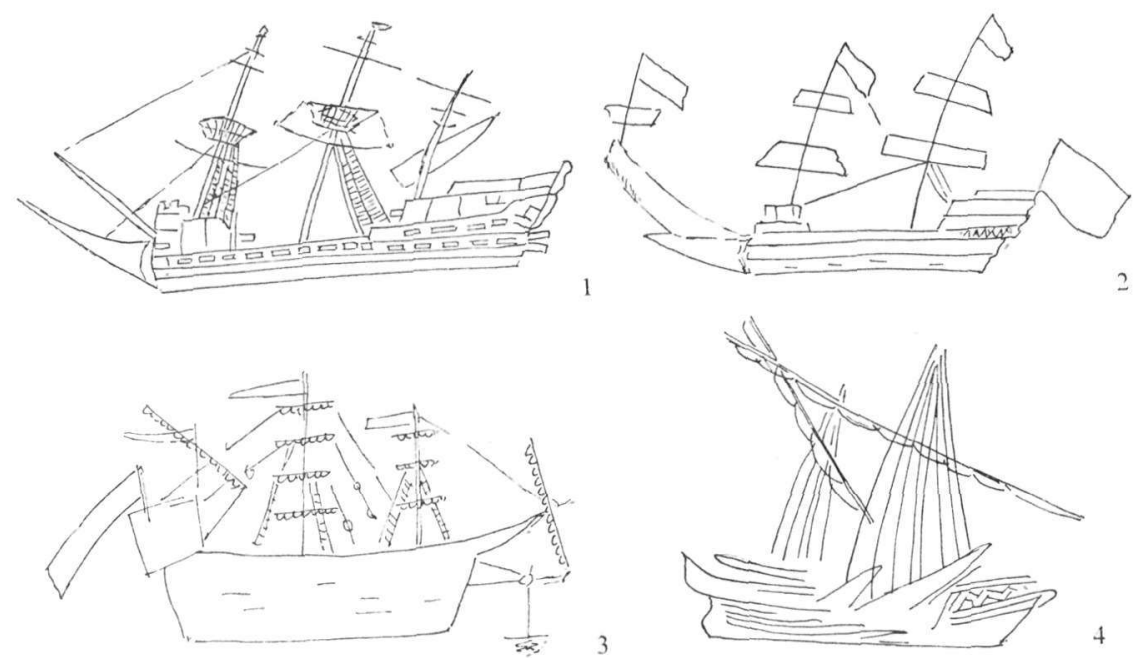

Fig. VIII.

This galleon had two complete decks and the upper deck could be covered with a boarding net. ${ }^{2}$

Fig. VIII, 2. Location: The Church of St. Luke of Stiris, east wall of the narthex of the subterranean Church of St. Barbara. This two-masted manof-war shows certain similarities to fig. VIII, 1. Noticeable is the long and heavy ram, which sits just above the water-level. Above the ram there is an even longer bowsprit with a spritsail. The foremast and the mainmast have two square sails respectively. Clearly visible is the mainstay connecting the mainmast with the forecastle. The aftercastle has three decks. The armament of this vessel is not portrayed, though we must assume that similarly to the ship of fig. VIII, 1 this galleon was armed with numerous guns. ${ }^{43}$

Fig. VIII, 3. Location: The Church of the Bl. Meletios, Attika. This galleon is a three-masted ship similar to fig. VIII, 1. The mainmast and the

42. C. A. A lexandris, op. cit., p. 400.

43. C. A. A lex andris, op. cit., p. 73. 
foremast have square sails, while the small mizzen has a lateen sail. Above the sturdy ram, which is high above the water-level, there is a long bowsprit with a spritsail. The aftercastle is merely indicated. The anchor is attached to the $\operatorname{ram}^{4 i}$

\section{The Caravel.}

The caraveI was the XVIth century replacement of the middle sized galley and was a favourite type of vessel in the Mediterranean. The rig of the caravel was very similar to that of the galleys with two or three masts, lateen rigged, of which the foremast was the taller. The height of the mainmast was about the same as the length of the ship on deck, and very often its yard was even longer than the ship so that it must have stuck out over bow and stern when lowered. The smaller round ships, the buss, had no rudder attached to the sternport, but instead they had one rudder projecting from each side of the poop.

Fig. VIII, 4. Location: Hephaistion, the sixth column from the east, northern row of columns. A two-masted round ship or buss, which was a very common vessel in the Mediterranean, used largely as a coastal trader. This type is similar to the navis bucius of the Genoese. ${ }^{43}$

Fig. IX, 1. Location: The Church of the Prophet Elias, Salonica, narthex. This vessel with the exceptionally long yard corresponds clearly to the description of the caravel. The ram above the water-line identifies this vessel as a man-of-war. The small mast on the stern had a lateen sail to help in the navigation of the ship.

Fig. IX, 2. Location: Hephaistion, south wall of the temple. This twomasted caravel was equipped with a powerful ram, thus indicating its use as a man-of-war. Noticeable is the bowsprit and the smaller foremast, the arbor de prova, and the larger mainmast, the arbor de medio. ${ }^{46}$

Fig. IX, 3. Location: The Church of St. Luke of Stiris, south wall of the gallery of the main church. This small man-of-war with a straight gunwale is a late XVth century caravel. A two-masted lateener, this ship had on its mainsail an additional topsail or crow's nest. The large spritsail is very prominent. The mizzen is clearly identifiable, though it is difficult to see the castle on the stern. The ram lies high above the water-level.

Fig. IX, 4. Location: Hephaistion, third column from the east, northern

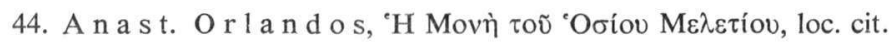

45. M. Goud a s, op. cit., No. 9.

46. M. Goud a s, op. cit., No. 20. 
row of columns. A typical caravel with two masts and a bowsprit. The aftercastle is elaborately designed with portholes and a railing. A railing is also indicated in the foreship. Noticeable are the large flags on the mainmast and the stern. ${ }^{47}$

Fig. X,1. Location: The Church of the Prophet Elias, Salonica, narthex. This unfinished akidographema represents a caravel. This ship is a man-
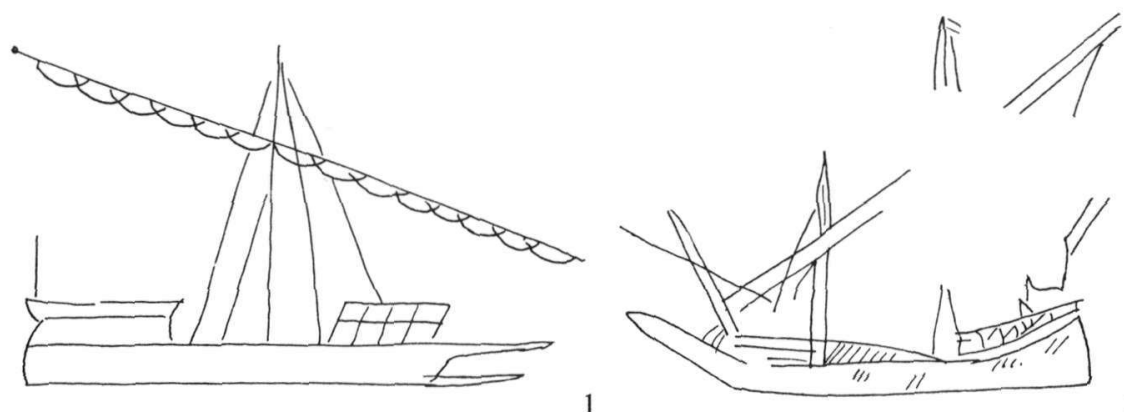

1
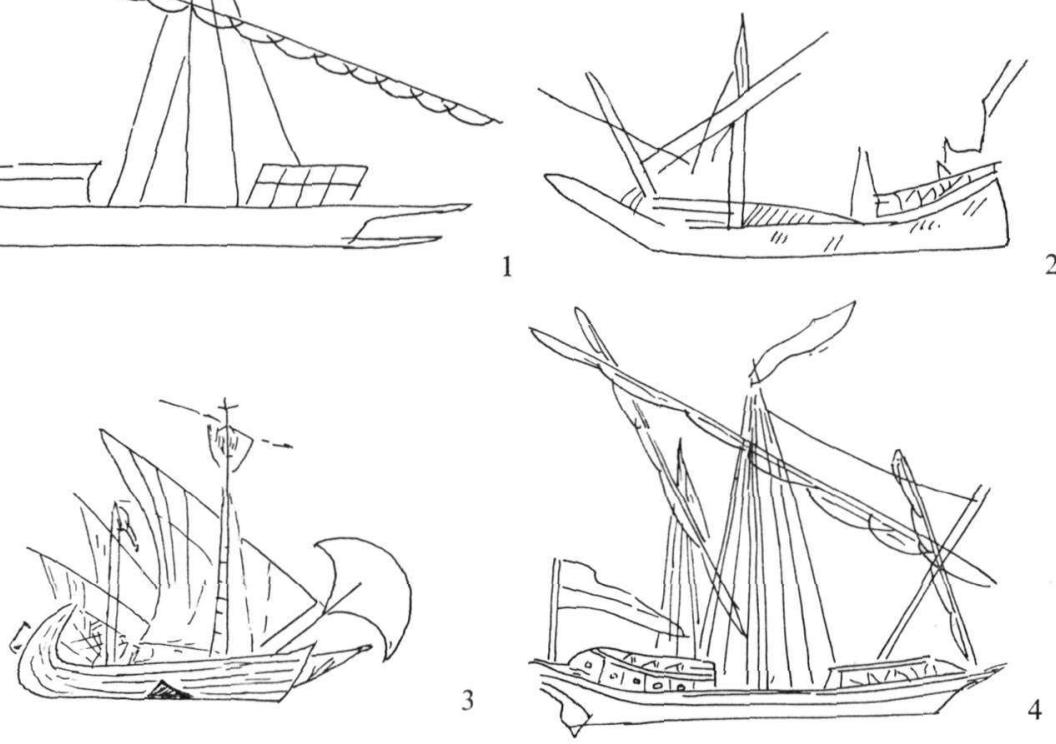

Fig. IX.

of-war as indicated by the ram. Noticeable is the tall foremast with a fightingplatform.

Fig. X, 2. Location: The Church of the Prophet Elias, Salonica, narthex. This threemasted ship (only one mast is shown) is a caravel. The bow is strengthened with additional planks and a ram. On the foremast we notice a spritsail. This ship is a man-of-war.

Fig. X, 3. Location : The former Church of Hagia Sophia in Trebizond. This type of vessel, though typical for the Black Sea, comes closest to the

47. M. G o u d a s, op. cit., No. 6 . 
caravel. These ships which were used in the XIIIth and XIVth century were as much as $110 \mathrm{ft}$. in length and ranged from 400 to 600 tons burthen. ${ }^{48}$

\section{The Carrack.}

By the XVIth century, the carrack and the cog had replaced the larger galleys. The carrack is a typical round ship, wide at the prow and the poop
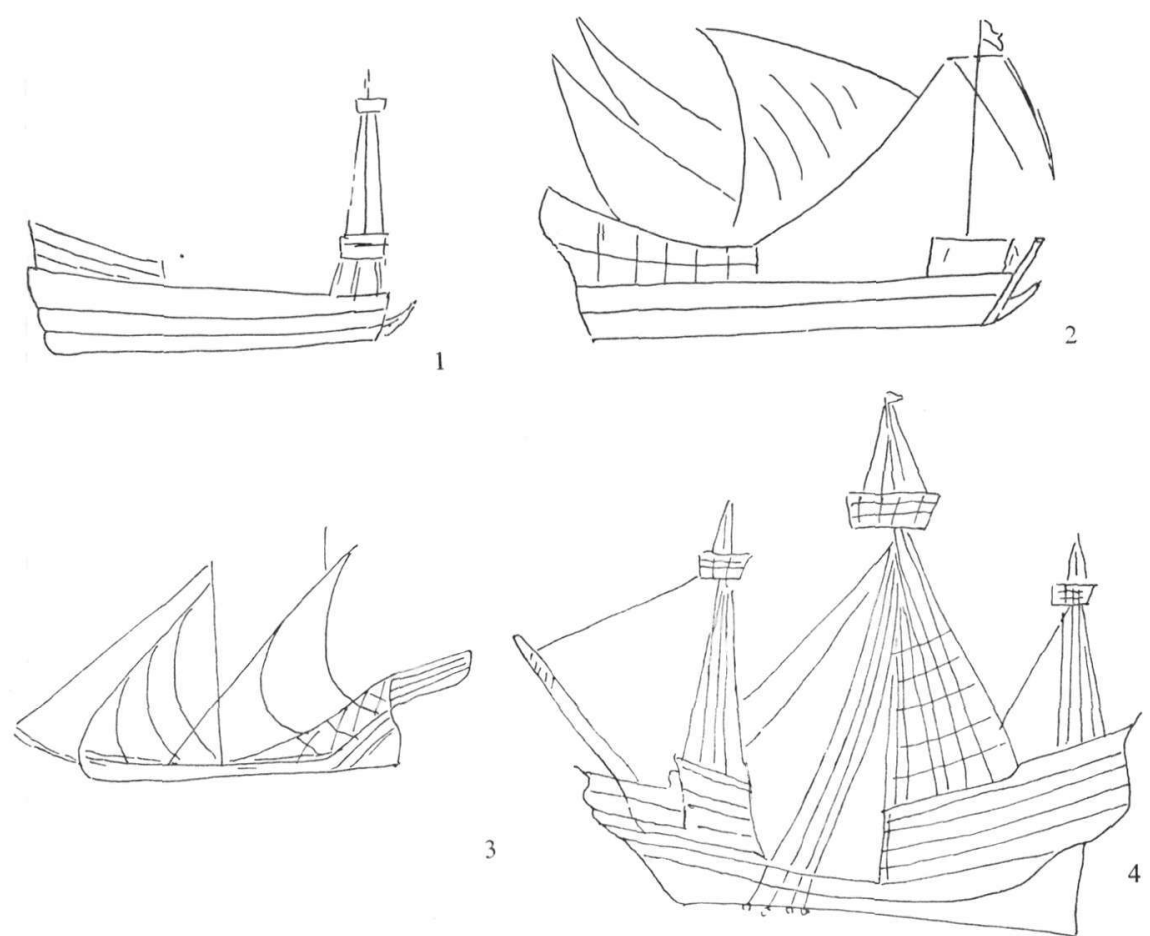

Fig. X.

and quite short for its width. This type of vessel rode high out of the water and was as deep as it was wide. Carracks and cogs were used in war and peace.

Fig. X, 4. Location: The Church of St. Luke of Stiris, north wall of the gallery of the main church. This three-masted carrack should be assigned to the XVth or XVIth century. The mainmast carries a large square sail. The smaller mast on the forecastle is also square-rigged while the mast on the aftercastle carries a lateen sail. All three masts show crow's nests. Noteworthy is the long bowsprit. The castles at the prow and the stern are neatly

48. A. B rye r, loc. cit. 


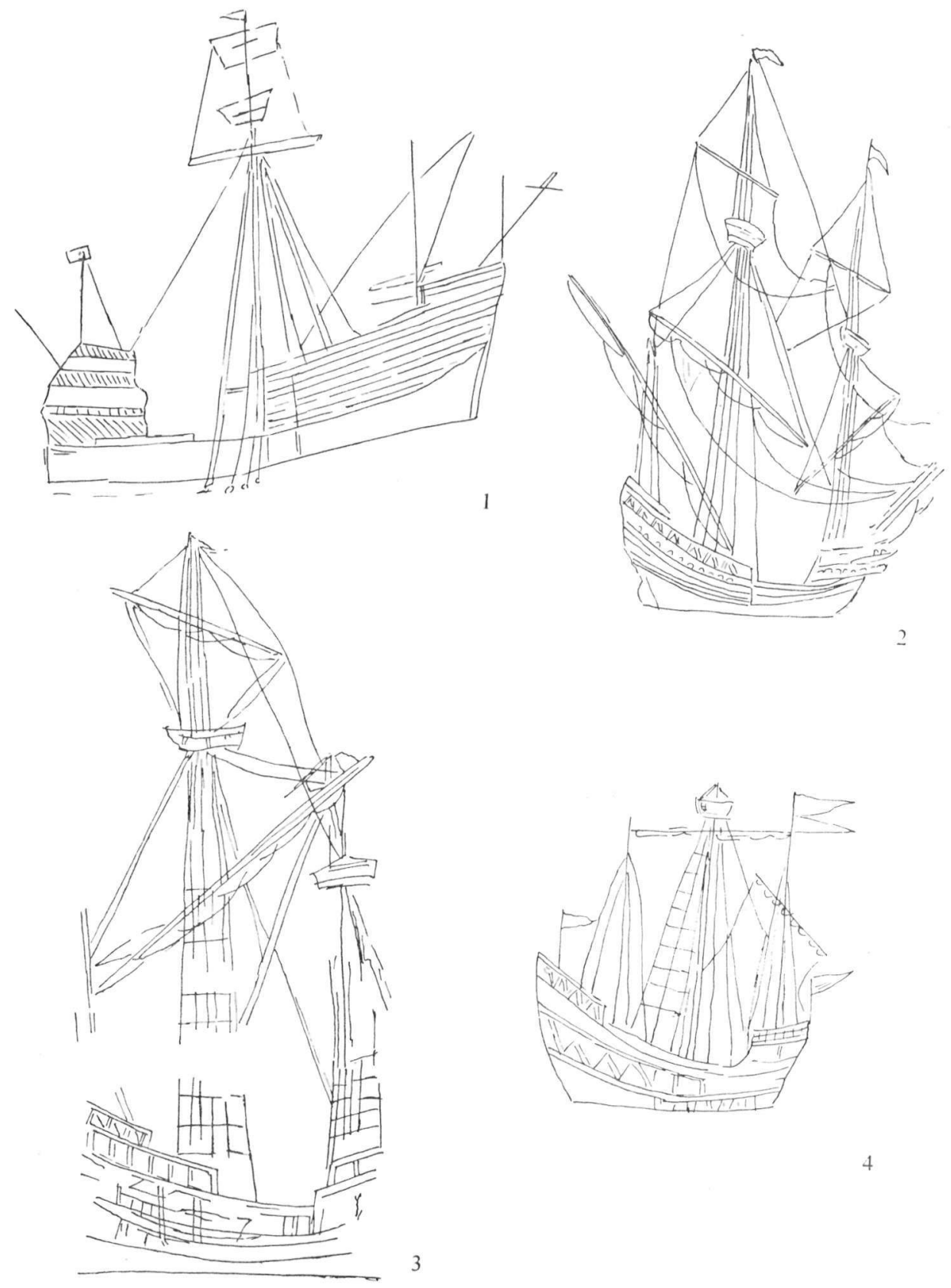

Fig. XI. 
absorbed into the lines of the ship so as to appear as an integral part of the hull. Indicated are a half-deck and a quarter-deck as well as two forecastle decks and the hatch. The rudder (not indicated) was attached to the stern. The main shrouds with ratlines are very prominent. This kind of ship, though slow and clumsy, was undoubtedly seaworthy and economical.

Fig. XI, 1. Location: The Church of St. Luke of Stiris, north wall of the gallery of the main church. A two-masted carrack (1496) with prominent mainmast. The crow's nest on the mainmast is surmounted by a square topsail set on a flagstaff. On the aftercastle we notice the bonaventura mast for the bonaventura mizzen. The four aftercastle decks are clearly portrayed. The upper deck is for the steersman and the compass. The second deck for the captain of the ship, the third and fourth decks for notable passengers and for the captain's treasures. The long half-deck, which is surmounted by a forecastle, is especially noticeable. The smaller foremast had a square sail. Clearly visible is the bowsprit for the spritsail.

Fig. XI, 2. Location: Hephaistion, sixth column from the west, southern row of columns. This akidographema portrays a majestic ship. The main and foremasts have a crow's nest surmounted by a square topsail. The long bowsprit is clearly noticeable, and on the stern there is the bonaventura mast with the bonaventura mizzen. The fore-and aftercastles show elaborate workmanship. Portholes are indicated in the aftercastle. ${ }^{49}$

Fig. XI, 3. Location: Hephaistion, southern column of the western row of columns. This akidographema is unfortunately damaged. With all probability it portrays the same vessel as in fig. XI, 2, though only the fore-and mainmasts and part of the stern are visible."

Fig. XI, 4. Location: Hephaistion, third column from the east of the northern row of columns. This three-masted carrack shows the kind of flush planking which became very widely used by the latter part of the XVth century. The fore-and mainmasts carry square sails, and on the aftercastle there is the bonaventura mast for the bonaventura mizzen. This carrack is one of the most beautifully designed akidographemata. ${ }^{31}$

Whereas it is not the purpose of this study to report in any detail about the custom of scratching ships in walls of churches and monasteries beyond the Byzantine realm, it might be of interest, nevertheless, to remind the reader that this practice was not limited to the region under discussion.

49. M. G o u d a s, op. cit., No. 16 .

50. M. G o u d a s, op. cit., No. 13.

51. M. G o u d a s, op. cit., No. 4. 
Thus, for example, Carl Sölver discovered an akidographema of a carrack on a burnt brick in the Carmelite Monastery of Helsingör, which he assigned to the first half of the XVth century. ${ }^{52}$

On the column E 14 on the northern side of the choir in the Kölner Dom, I noticed an akidographema of a cog belonging to the XVth or XVIth century. ${ }^{33}$ The custom of scratching votive representations in walls of churches and monasteries must have extended, therefore, throughout the mediaeval world in Orient and Occident.

OTTO F. A. MEINARDUS

52. C. S ölve r, "Ett betydelsfullt Fynd”, Segel och Motor (Stockolm), 1936. VIII. H. W inter, "Schiffsbilder auf Ziegelsteinen», Forschungen und Fortschritte XIII, $35 / 36,1937$, p. 415 .

53. O. M e in a rdu s, Ein Schiffsgraffito im Kölner Dom, Kölner Domblatt, Jahrbuch des Zentral-Dombauvereins, 1971. 

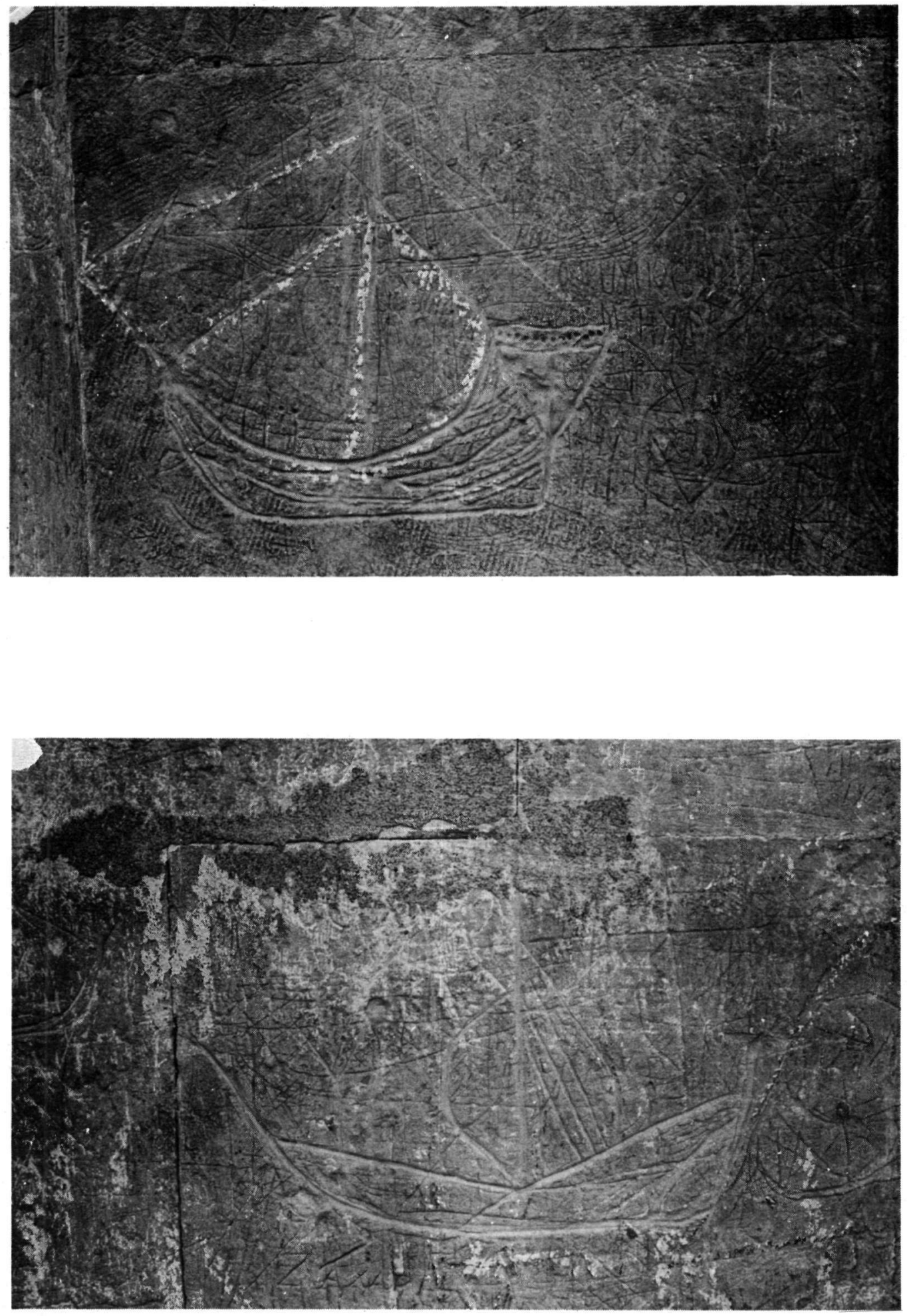

a.-b. Church of Hagia Sophia in Trebizond. 

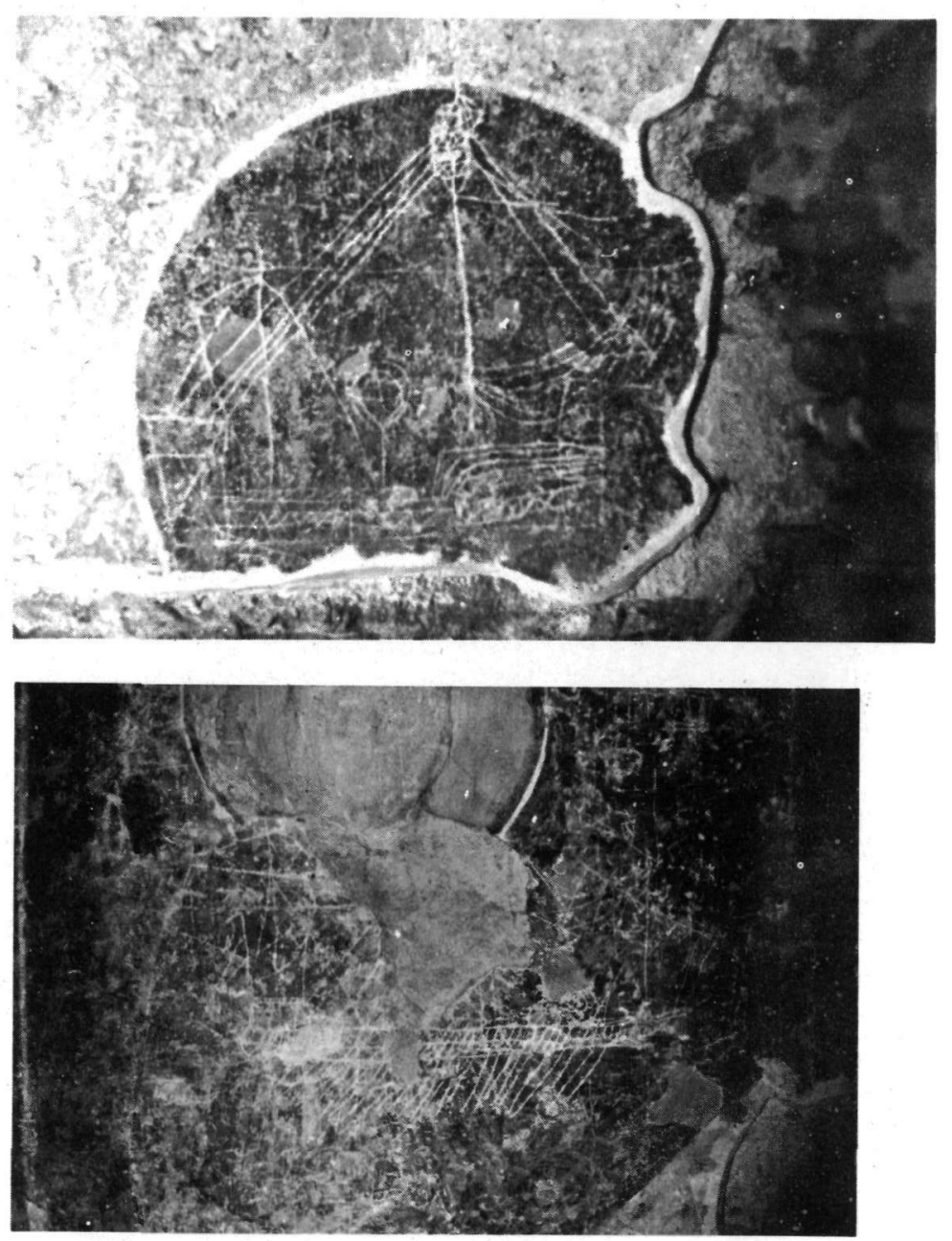

a.-b. Church of St. Luke of Stiris.

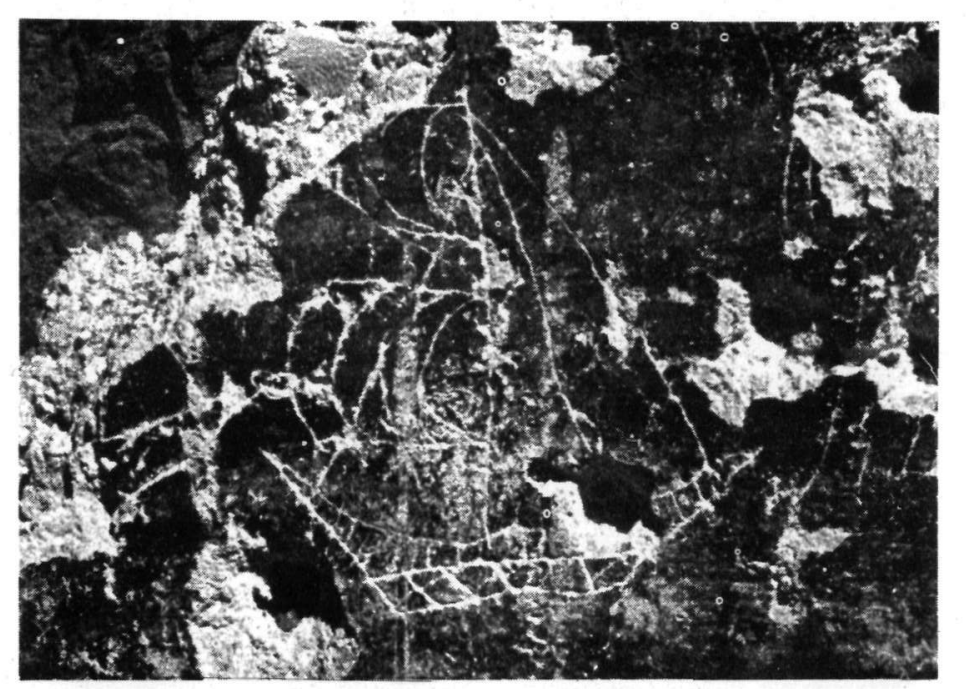

c. Church of the Holy Virgin in the Monastery of the Panagia Soumela near Maçka.

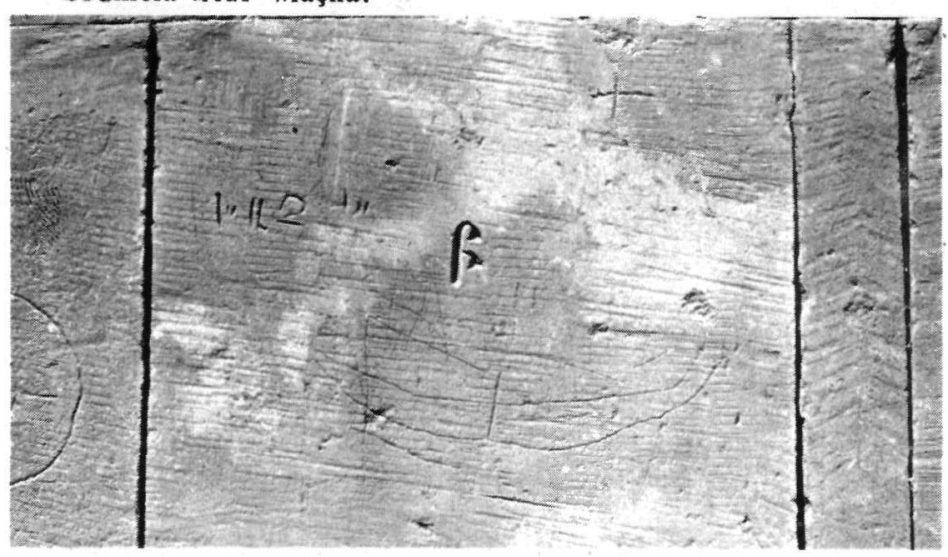

d. Armenia. Orthodox Monastery of St. Thaddaius near Shahabad, Makoo. 

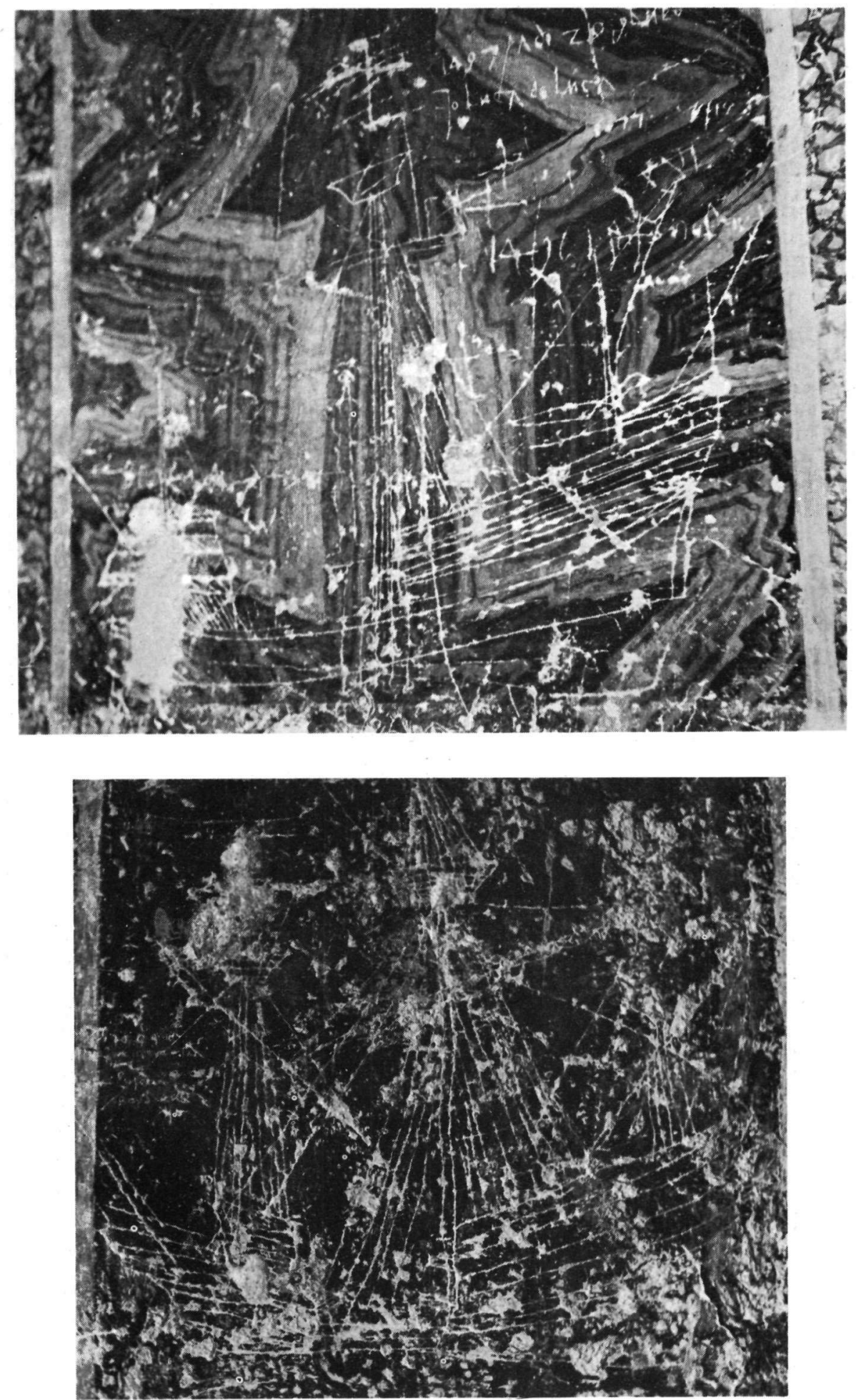

a.-b. Church of St. Luke of Stiris. 

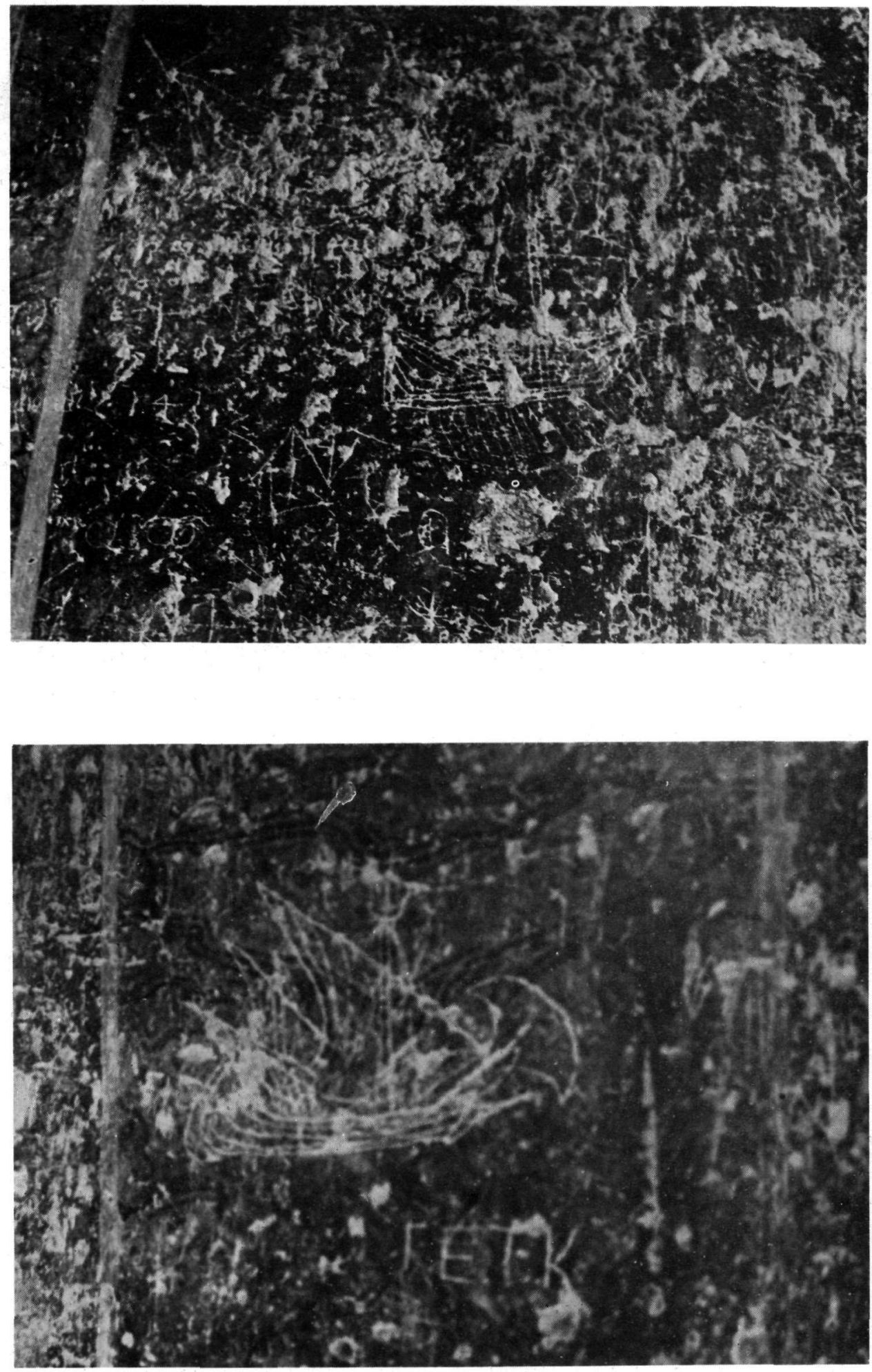

a.-b. Church of St. Luke of Stiris. 